\title{
Thyroid Gland Volume in Adults with Epilepsy: Relationship to Thyroid hormonal function
}

Sherifa A.Hamed ${ }^{1}$, Mostafa A. Haridi2, Mahmoud M. Hassan ${ }^{3}$, Mostafa E. Radwan ${ }^{4}$

\section{Abstract}

Several studies were done investigating thyroid function in patients with epilepsy. However the results of different studies were conflicting or controversial. This study aimed to evaluate thyroid hormonal changes and their relationship to thyroid volume in epileptic adults on long-term treatment with antiepileptic drugs (AEDs). This study included 135 adults with idiopathic epilepsy with mean age of $32.32 \pm 4.34$ years, duration of illness of $10.52 \pm 5.08$ years and on treatment with carbamazepine (CBZ), valproate (VPA) or CBZ+VPA for a mean duration of $8.66 \pm 3.32$ years. The serum levels of free thyroxine (fT4), triiodothyronine (fT3), and thyroid-stimulating hormone (TSH) were assessed. Thyroid volume was measured using ultrasonography. Compared to control subjects, patients had significant lower fT4 $(p<0.01)$ and fT3 $(p<0.01)$ and higher levels of TSH $(p<0.0001)$. The majority of patients with reduced fT4 also had reduced fT3 and increased TSH levels. Nearly $26 \%$ of the patients had enlargement of the thyroid gland $(p<0.001)$. Patients on polytherapy had more thyroid volume compared to patients on monotherapy $(p<0.05)$ and patients on VPA had more thyroid volume compared to patients on CBZ $(p<0.03)$. All patients were clinically euthyroid. Significant correlations were identified between $\mathrm{fT} 4$ concentrations and duration of illness, dose, serum level and duration of AEDs treatment, fT3 and TSH concentrations and between thyroid volume and fT4, fT3 and TSH concentrations. In conclusion, CBZ and VPA as mono- or polytherapies may cause thyroid hormonal and structural abnormalities. Thyroid enlargement is due to associated subclinical hypothyroidsm. This data have implications suggesting prevention strategies. 
Key words: Epilepsy; antiepileptic drugs; subclinical hypothyroidism, thyroid volume

Abbreviations: AEDs, Antiepileptic drugs; CBZ, carbamazepine; VPA, valproate; fT3, free triiodothyronine; fT4, free thyroxine; TSH, thyroid stimulating hormone; SCH, subclinical hypothyroidism

\section{Introduction}

Epilepsy is a common chronic medical problem and often requires long-term therapy, which may even continue throughout life (1). Disturbances in endocrine hormones have been reported in patients with epilepsy and with some antiepileptic drugs (AEDs), among are thyroid hormones. The majority of the studies suggested that the changes of thyroid hormones in epileptics were due to the effect of some AEDs and not the due to the disease itself $(2,3)$. Earlier studies frequently reported abnormal thyroid hormonal levels with enzyme inducing AEDs [carbamazepine (CBZ), phenytoin (PHT) and phenobarbital (PB)]. These abnormalities included reduced serum concentrations of total thyroxine (T4), free $\mathrm{T} 4$ ( $\mathrm{fT} 4)$, tri-iodothyronine (T3), free T3 (fT3), free T4-index (fT4I), free T3-index (fT3I), thyroxine binding globulin (TBG) and increased concentrations of thyroid stimulating hormone (TSH) (2-6). Also earlier studies reported normal thyroid hormonal levels with non-enzyme inducing AED (valproate or VPA) which included normal concentrations of T4 (7-9), T3, T3 uptake (T3U) and thyrotropin (TSH) and thyrotropin releasing hormone (TRH) stimulation (4,7,10-16). Further studies reported that non-enzyme inducing AED (valproate or VPA) is also associated with thyroid hormonal dysfunction (17-25). None of these studies reported overt manifestations of thyroid abnormalities. Reduction in fT4 and increase in TSH levels were reported as early as one to three months after starting treatment with CBZ, PB or VPA (20, 25). Also, previous studies demonstrated that the changes induced by these drugs are transient $(4,16)$. Studies reported increase in serum concentrations of fT4, fT3 and reduction of TSH and restoration of euthyroid state several months following AED withdrawal even after years of treatment $(26,27)$ or with L-thyroxine substitutive supplement (28).

Few studies were done to assess thyroid volume in patients with epilepsy and on AEDs. Some studies reported ultrsongraphic evidence of thyroid enlargement (goiter). Also, these studies reported significant correlation between thyroid volume and thyroid hormonal abnormalities $(5,29)$.

Induction of metabolism of thyroid hormones by the hepatic microsomal enzyme system has been suggested as the main mechanism for decreased serum T4, fT4, T3 and fT3 concentrations with enzyme inducing AEDs. The reduction in thyroid hormone concentrations in the periphery is associated with compensatory increase in the serum TSH enhancement. Some suggested that interference with hypothalamic regulation of thyroid function by AEDs seems a possible mechanism for thyroid hormonal abnormalities with AEDs (30). The development of high levels of TSH more than $5 \mathrm{mlU} / \mathrm{mL}$ is known as subclinical hypothyroidism (SCH). However, the mechanism of thyroid hormonal with non-enzyme inducing VPA is unclear. The increase in the concen- 
tration of T3 reported by some authors with AEDs (13) could be explained as a mechanism of the body to counteract the impact of diminishing production of T4 through a preferential thyroidal secretion of T3 and enhanced conversion of T4 into T3 particularly in the early stage of development of hypothyroidism. Some suggested that increased T3 may result from augmented T4 to T3 conversion rate due to accelerated T4 metabolic clearance (31).

\section{Aim of work}

Although thyroid function has been frequently investigated in patients with epilepsy, however conflicting data exist for the influence and mechanisms of AEDs on thyroid function. In addition, data regarding the predictors for thyroid enlargement (goiter) with epilepsy are still unknown. This study aimed to investigate the functional and volume changes of the thyroid gland in adults with epilepsy and on long-term AEDs.

\section{Materials and Methods}

\section{Subjects}

This is a cross-sectional study. It included 135 adult patients with idiopathic epilepsy (male $=88$, females $=47$ ) with age ranged between 20 to 50 years (mean: $32.32 \pm 4.34$ ), duration of illness of 5 to 20 years (mean: $10.52 \pm 5.08$ ) and on chronic treatment with CBZ $(n=65)$, VPA $(n=30)$ or CBZ+VPA $(n=40)$ for a duration ranged between 6 to 15 years (mean: $8.66 \pm 3.32$ ). Table (1) showed the demographic, clinical and laboratory features of the studied patients. Epilepsy type was classified according to the recommendations of the International League Against Epilepsy (32). Patients were recruited from the out-patient epilepsy clinic of Assiut and Al-Azhar University Hospitals, Assiut, Egypt. Sixty normal healthy subjects matched for age, sex and socioeconomic status were chosen as control subjects for statistical comparisons. Control subjects were recruited from the general population. The protocol of the study was reviewed and approved by the ethical committee of Assiut and Al-Azhar University Hospitals and all subjects in this study gave their informed consent before participation.

All participants were subjected to full medical, endocrinological and neurological histories and examinations. Biological variables collected included: age, gender and body mass index (BMI). Seizures were analyzed determining seizure type, duration of illness, duration of treatment with AEDs and the degree of response to AEDs. Patients were considered controlled on AEDs when seizure free for $\geq 1$ year. Patients with diseases other than epilepsy, iodine deficiency conditions, family history of thyroid disease, history of thyroid surgery, manifestations of a pituitary mass or of hypopituitarism (which suggest the presence of central hypothyroidism) or taking regular medication(s) beside AEDs, were excluded.

\section{Specimen collection and analysis}

After an overnight fast and patients were seizure free for at least 72 hours [as any postictal central hormonal dysfunction is recognized to reverse within hours], blood samples were drawn at (8.00-10.00 a.m.) for routine testing as complete blood count $(\mathrm{CBC})$, fasting blood glucose (FBG), and serum levels of creatinine, aspartat amino transferase (AST), alanine amino transferase (ALT) and gamma glutamyl transferase (GGT). The rest of serum sample was kept frozen at $-70^{\circ} \mathrm{C}$ in aliquots for the assay of serum levels of AEDs, fT3, fT4 and TSH. Hormonal concentrations and serum drug levels were measured as part of the investigation in batched assays. For all patient and control subjects, the serum concentrations of fT4, fT3 and TSH were measured by immunoenzymetric assay kits (IMMULITE reproductive hormone assays by kits obtained from DPC 
or Diagnostic Products Corporation, Los Angeles, USA as described by the manufacturer (33-35). The serum level of $A E D(s)$ were determined in the therapeutic drug monitoring (TDM) lab, Assiut University Hospital, Assiut Egypt, by fluorescence polarization immunoassay system of Abbott (EPIA) using TDxFLX apparatus (Abbott Lab, Wiesbaden, Germany) (17).

\section{Ultrasonography (US) of the thyroid}

Ultrasonography was done by the same radiologist using a real time ultrasound equipment capable of B-mode imaging, pulsed wave duplex scanning, color Doppler flow imaging and power Doppler imaging (GE, LOGIQ 3 Color Doppler Machine, Korea). A 7.5-MHz linear transducer Bmode was used for measurement. The volume of each lobe was calculated using the formula for a prolate ellipse: (Volume $=0.5$ [length $(\mathrm{L}$ ) $x$ anterior-posterior depth (D) $x$ transverse width (W)]. Longitudinal and transverse images of the right and left thyroid lobes were obtained to show their maximal linear dimensions. All measurements were performed with electronic calipers on the frozen B-scan image (36).

\section{Statistical analysis}

Data were expressed as means \pm SD. Calculations were done with the statistical package SPSS for windows, version 12.0 (SPSS Inc., Chicago, IL, USA). Student's t-test was used to compare between means. Pearson's correlation coefficient was used to look for association between different metabolic variables. For all tests, values of $\mathrm{P}<0.05$ (two-tailed) were considered statistically significant.
Table 1. Demographic and clinical features of the studied patients

\begin{tabular}{|c|c|}
\hline Age; years & $20-50(32.32 \pm 4.34)$ \\
\hline Gender (Male/Female) & $88 / 47$ \\
\hline $\begin{array}{l}\text { Body mass index } \\
\text { (BMI); } \mathrm{kg} / \mathrm{m}^{2}\end{array}$ & $16-40(25.89 \pm 2.69)$ \\
\hline $\begin{array}{l}\text { Duration of illness; } \\
\text { years }\end{array}$ & $5-20(10.52 \pm 5.08)$ \\
\hline \multicolumn{2}{|l|}{ Type of epilepsy: } \\
\hline $\begin{array}{l}\text { Generalized tonic-clonic } \\
\text { epilepsy }\end{array}$ & $58(42.96 \%)$ \\
\hline $\begin{array}{l}\text { Complex partial/Partial } \\
\text { epilepsy with secondary } \\
\text { generalization }\end{array}$ & 77 (57.04\%) \\
\hline
\end{tabular}

\begin{tabular}{l|l}
\multicolumn{2}{l}{ Antiepileptic drugs (AEDs) utilized: } \\
\hline Carbamazepine (CBZ) & $65(48.15 \%)$ \\
Valproate (VPA) & $30(22.22 \%)$ \\
\hline CBZ+VPA & $40(29.63 \%)$
\end{tabular}

\section{Dose of AED; mg/day}

CBZ

$400-1200(650.55 \pm 289.83)$

VPA

$1000-2250(1250.00 \pm 250.00)$

Duration of $6-15(8.66 \pm 3.32)$

treatment; years

\begin{tabular}{|c|c|}
\hline \multicolumn{2}{|c|}{ Serum drug level; $\mu \mathrm{g} / \mathrm{ml}$} \\
\hline CBZ & $4.5-11.0(8.02 \pm 3.05)$ \\
\hline VPA & $70.04-105.50(90.55 \pm 25.50)$ \\
\hline
\end{tabular}

\section{Degree of control on AED(s)}

Controlled (seizure free 85 (62.96\%)

for $\geq 1$ year)

Uncontrolled

$50(37.04 \%)$

Values are expressed as mean \pm SD and number (\%).

\section{Results}

Patients had normal ALT and AST and GGT. Compared to control subjects, patients had significant lower serum levels of fT4 $(p<0.01)$ and fT3 $(p<0.01)$ and higher levels of TSH $(p<0.0001)$. Marked abnormalities were observed in patients on polytherapy (CBZ+VPA) compared to patients on monotherapy 
(CBZ or VPA). The majority of patients with reduced serum levels of $\mathrm{fT} 4$ had also reduced levels of fT3 and increased levels of TSH. Nearly $26 \%$ of the patients had increase in the thyroid gland volume $(p<0.001)$ (versus $6.7 \%$ for control subjects). Patients on polytherapy had more thyroid gland volume compared to patients on monotherapy $(p<0.05)$ and patients on VPA had more thyroid gland volume compared to patients on CBZ $(p<0.03)$ (table 2). All patients were clinically euthyroid. Compared to patients without SCH $(n=59)$, patients with $\mathrm{SCH}(n=76)$ were older, had longer duration of illness, higher doses of AEDs, higher serum levels of AEDs and longer duration of treatment on AEDs (table 3). No significant differences were identified in the serum levels of fT4, fT3, TSH or thyroid volume between patients who were controlled or those who were uncontrolled on AEDs. Correlations between demo-

Table 2. Thyroid hormonal and volume results of the studied groups

\begin{tabular}{|c|c|c|c|c|c|}
\hline Variable & $\begin{array}{l}\text { Patients } \\
(n=135)\end{array}$ & $\begin{array}{l}\text { Patients on CBZ } \\
\quad(n=65)\end{array}$ & $\begin{array}{c}\text { Patients on } \\
\text { VPA } \\
(n=30)\end{array}$ & $\begin{array}{l}\text { Patients on } \\
\text { CBZ+VPA } \\
(n=40)\end{array}$ & $\begin{array}{l}\text { Controls } \\
(n=60)\end{array}$ \\
\hline fT4; ng/ml & $\begin{array}{c}76(56.30 \%) \\
1.06-4.63 \\
1.98 \pm \pm 0.38\end{array}$ & $\begin{array}{c}31(47.69 \%) \\
1.26-3.37 \\
1.44 \pm \pm 0.50\end{array}$ & $\begin{array}{c}18(60 \%) \\
1.06-4.63 \\
1.84 \pm \pm 0.30\end{array}$ & $\begin{array}{c}26(65 \%) \\
0.26-2.86 \\
0.96 \pm \pm 0.30\end{array}$ & $\begin{array}{c}5(8.33 \%) \\
1.75-3.85 \\
2.39 \pm \pm 0.45\end{array}$ \\
\hline $\begin{array}{l}\text { P1 } \\
\text { P2 } \\
\text { P3 }\end{array}$ & $\begin{array}{c}0.010 \\
- \\
-\end{array}$ & $\begin{array}{l}\mathbf{0 . 0 1 0} \\
>0.05 \\
\mathbf{0 . 0 4 5}\end{array}$ & $\begin{array}{c}0.010 \\
- \\
0.036\end{array}$ & $\begin{array}{c}0.001 \\
- \\
-\end{array}$ & $\begin{array}{l}- \\
- \\
-\end{array}$ \\
\hline fT3; pg/ml & $\begin{array}{c}52(38.52 \%) \\
1.52-4.64 \\
1.90 \pm \pm 0.22\end{array}$ & $\begin{array}{c}23(35.38 \%) \\
2.23-4.43 \\
2.56 \pm \pm 0.32\end{array}$ & $\begin{array}{c}11(36.67 \%) \\
1.67-4.64 \\
2.05 \pm \pm 0.66\end{array}$ & $\begin{array}{c}18(45 \%) \\
1.52-3.86 \\
1.85 \pm \pm 0.72\end{array}$ & $\begin{array}{c}2(3.33 \%) \\
1.73-4.95 \\
3.86 \pm \pm 0.53\end{array}$ \\
\hline $\begin{array}{l}\text { P1 } \\
\text { P2 } \\
\text { P3 }\end{array}$ & $\begin{array}{c}0.010 \\
- \\
-\end{array}$ & $\begin{array}{l}\mathbf{0 . 0 1 0} \\
>0.05 \\
>0.05\end{array}$ & $\begin{array}{c}\mathbf{0 . 0 1 0} \\
- \\
>0.05\end{array}$ & $\begin{array}{c}0.010 \\
- \\
-\end{array}$ & $\begin{array}{l}- \\
- \\
-\end{array}$ \\
\hline TSH; mIU/L & $\begin{array}{c}56(41.48 \%) \\
3.37-12.00 \\
7.68 \pm \pm 0.42\end{array}$ & $\begin{array}{c}24(36.92 \%) \\
3.37-10.52 \\
6.42 \pm \pm 0.34\end{array}$ & $\begin{array}{c}10(33.33 \%) \\
2.76-11.43 \\
6.88 \pm \pm 0.64\end{array}$ & $\begin{array}{c}22(55 \%) \\
4.22-12.00 \\
8.06 \pm \pm 0.38\end{array}$ & $\begin{array}{c}7(11.67 \%) \\
2.85-4.60 \\
2.54 \pm \pm 0.67\end{array}$ \\
\hline $\begin{array}{l}\text { P1 } \\
\text { P2 } \\
\text { P3 }\end{array}$ & $\begin{array}{c}0.0001 \\
- \\
-\end{array}$ & $\begin{array}{c}\mathbf{0 . 0 0 0 1} \\
>0.05 \\
\mathbf{0 . 0 1 0}\end{array}$ & $\begin{array}{l}0.0001 \\
- \\
0.010\end{array}$ & $\begin{array}{c}0.0001 \\
- \\
-\end{array}$ & $\begin{array}{l}- \\
- \\
-\end{array}$ \\
\hline Thyroid volume; ml & $\begin{array}{c}35^{*}(25.93 \%) \\
10.54-58.40 \\
24.64 \pm \pm 3.30\end{array}$ & $\begin{array}{c}8^{*}(12.31 \%) \\
10.54-47.84 \\
22.55 \pm \pm 3.62\end{array}$ & $\begin{array}{c}9 *(30 \%) \\
12.54-48.45 \\
25.08 \pm \pm 2.32\end{array}$ & $\begin{array}{c}18^{*}(45 \%) \\
14.08-58.40 \\
28.96 \pm \pm 2.08\end{array}$ & $\begin{array}{c}4^{*}(6.67 \%) \\
9.75-42.82 \\
14.53 \pm \pm 2.64\end{array}$ \\
\hline $\begin{array}{l}\text { P1 } \\
\text { P2 } \\
\text { P3 }\end{array}$ & $\begin{array}{c}0.001 \\
- \\
-\end{array}$ & $\begin{array}{l}0.001 \\
0.030 \\
0.010\end{array}$ & $\begin{array}{c}0.001 \\
- \\
0.043\end{array}$ & $\begin{array}{c}0.001 \\
- \\
-\end{array}$ & $\begin{array}{l}- \\
- \\
-\end{array}$ \\
\hline
\end{tabular}

Data are expressed as means $\pm S D$, number (\%) of patients with abnormal results.

fT3, free triiodothyronine; fT4, free thyroxine; TSH, thyroid stimulating hormone

P1: significance versus controls, P2: significance versus VPA, P3: significance versus CBZ+VPA

*: Number of patients with thyroid enlargement (goiter) 
Table 3. Demographic and clinical features and thyroid volume in relationship to the presence or absence of subclinical hypothyroidism

\begin{tabular}{|c|c|c|c|}
\hline Demographic and clinical features & $\begin{array}{l}\text { Patients with } \\
\text { subclinical } \\
\text { hypothyroidism } \\
(\mathrm{n}=76)\end{array}$ & $\begin{array}{l}\text { Patients without } \\
\text { subclinical } \\
\text { hypothyroidism } \\
(n=59)\end{array}$ & P-value \\
\hline Age & $38.53 \pm 2.66$ & $30.02 \pm 3.82$ & 0.010 \\
\hline Gender (Male/Female) & $45 / 31$ & $43 / 16$ & - \\
\hline Body mass index (BMI) & $22.54 \pm 2.40$ & $26.64 \pm 3.66$ & 0.089 \\
\hline Duration of illness & $15.63 \pm 3.53$ & $8.86 \pm 2.45$ & 0.001 \\
\hline \multicolumn{4}{|l|}{ Type of epilepsy: } \\
\hline Generalized tonic-clonic epilepsy & $22(28.95 \%)$ & $36(61.02 \%)$ & - \\
\hline $\begin{array}{l}\text { Complex partial/Partial epilepsy with } \\
\text { secondary generalization }\end{array}$ & $54(71.05 \%)$ & $23(38.98 \%)$ & - \\
\hline \multicolumn{4}{|l|}{ Antiepileptic drugs (AEDs) utilized } \\
\hline CBZ & $32(42.11 \%)$ & $33(55.93 \%)$ & - \\
\hline VPA & $18(23.68 \%)$ & $12(20.34 \%)$ & - \\
\hline$C B Z+V P A$ & $26(34.21 \%)$ & $14(23.73 \%)$ & - \\
\hline \multicolumn{4}{|l|}{ Dose of AED } \\
\hline CBZ & $850.00 \pm 200.50$ & $400.50 \pm 150.00$ & 0.001 \\
\hline VPA & $1400.00 \pm 250.00$ & $1000.00 \pm 350.80$ & 0.010 \\
\hline Duration of treatment & $13.45 \pm 4.46$ & $6.47 \pm 2.82$ & 0.001 \\
\hline \multicolumn{4}{|l|}{ Serum drug level } \\
\hline CBZ & $10.45 \pm 1.62$ & $6.88 \pm 1.45$ & 0.010 \\
\hline VPA & $100.40 \pm 25.35$ & $70.65 \pm 15.25$ & 0.001 \\
\hline \multicolumn{4}{|l|}{ Degree of control on AED(s) } \\
\hline Controlled (seizure free for $\geq 1$ year) & $54(71.05 \%)$ & $31(52.54 \%)$ & - \\
\hline Uncontrolled & $22(28.95 \%)$ & $28(47.46 \%)$ & - \\
\hline \multirow[t]{2}{*}{ Thyroid volume } & $35^{\star}(46.05 \%)$ & $59(0 \%)$ & - \\
\hline & $24.64 \pm \pm 3.30$ & $15.64 \pm \pm 3.53$ & 0.001 \\
\hline
\end{tabular}

Values are expressed as mean \pm SD and number (\%)

*: Number of patients with thyroid gland enlargement (goiter) 
graphic, clinical, laboratory and US characteristics of the studied group revealed significant correlations between the followings: 1) fT4 concentrations and duration of illness $(r=-0.362, p=0.043)$, dose of AED (CBZ: $r=-0.508, p=0.001$; VPA: $r=-0.638$, $p=0.001)$, serum level of AED (CBZ: $r=-0.742$, $p=0.001$; VPA: $r=-0.570, p=0.001)$, duration of treatment $(r=-0.456, p=0.01)$, fT3 concentrations $(r=0.456, p=0.01)$, TSH concentrations $(r=$ $-0.854, p=0.0001)$ and thyroid volume $(r=-0.576$, $p=0.001), 2)$ fT3 concentrations and fT4 concentrations ( $r=0.456, p=0.01)$, TSH concentrations $(r=$ $-0.632, p=0.001)$ and thyroid volume $(r=-0.388$, $p=0.042)$, 3) TSH concentrations and dose of AED (CBZ: $r=0.623, p=0.001 ;$ VPA: $r=0.568, p=$ $0.007)$, duration of treatment $(r=0.577, p=0.006)$, fT4 concentrations $(r=-0.854, p=0.0001)$, fT3 concentrations ( $r=-0.632, p=0.001)$ and thyroid volume ( $r=0.680, p=0.001)$, and 4 ) No significant correlations were found between serum levels of fT4, fT3 or TSH and GGT concentrations.

\section{Discussion}

The results of this study indicate that adults with epilepsy and on long-term treatment with enzymeinducing and non-enzyme inducing old AEDs experience the followings: 1) high frequency of subclinical hypothyroidism (SCH) as evidenced by lower serum concentrations of fT4 and fT3 and higher concentrations of TSH. These changes occurred regardless to the type of epilepsy or the degree of control on AEDs, 2) a significant frequency of patients with $\mathrm{SCH}$ had ultrasonographic evidence of thyroid enlargement (goiter), 3) patients on polytherapy showed marked abnormalities and more increase in thyroid volume compared to those on monotherapy, 4) age, duration of illness, duration of treatment and dose and serum level of AEDs are risk factors for SCH. The latter is a risk factor for thyroid enlargement, and 5) The presence of abnormalities of thyroid hormones and volume with CBZ and VPA and normal GGT (a marker of liver enzyme induction), highly suggest the presence of mechanisms other that enzyme induction that may contribute to thyroid hormonal and structural abnormalities among patients with epilepsy.

In this study, SCH was reported in approximately half of the epileptic patients (i.e. reduced fT4 and fT3 and increased TSH in 56.30\%, 38.52\% and $41.48 \%$ versus $8.33 \%, 3.33 \%$ and $11.67 \%$ of control subjects, respectively). With CBZ, we reported $\mathrm{SCH}$ in 1/3-1/2 of patients (i.e. reduced fT4 and fT3 and increased TSH in 47.69\%, 35.38\% and $36.92 \%$ ). With CBZ, Yilmaz et al. (25) reported SCH in $13.9 \%$, Isojarvi et al. (8) reported reduced levels of $\mathrm{T} 4$ in $53.3 \%$, fT4 in $28.9 \%$ and Eiris-Punal et al. (15) reported increased levels of TSH in $8.2 \%$ (versus 3.6\% for controls). With VPA, we reported $\mathrm{SCH}$ in $1 / 3-2 / 3$ of patients (i.e. reduced fT4 and fT3 and increased TSH in 47.69\%, 35.38\% and $36.92 \%$ ). Previous studies reported $\mathrm{SCH}$ in $25.2 \%$ (19), 19.6\% (22), 52.4 (23), 26\% (24) and 28\% (25) with VPA. We reported SCH in more than 1/3-1/2 of patients on combined therapy (CBZ + VPA) (fT4 = 65\%; fT3 = 45\%; TSH = 55\%). Isojarvi et al. (8) reported reduced levels of fT4 in $50-100 \%$ of patients on CBZ-VPA. Previous studies reported that polytherapy was associated with $\mathrm{SCH}(19,23)$. The altered thyroid function during CBZ medication and been attributed to induction of the hepatic P-450 enzyme system and the consequent increase in the metabolism of thyroid hormones $(3-6,11,37)$. The presence of normal GGT and the presence of thyroid abnormalities with VPA highly suggest that there are other mechanisms which induce thyroid hormonal abnormalities in patients with epilepsy and on AEDs. Hypothalamic interference of regulation of thyroid hormone production by AEDs seems possible. In addition, some authors suggested that there are other mechanisms which may result in thyroid abnormalities with CBZ other than enzyme 
induction. Villa et al. (38) suggested that inhibition of iodine uptake by the thyroid gland might be one of the mechanisms by which CBZ can induce thyroid dysfunction. Surks and DeFesi (39) showed that patients taking CBZ medication had low fT4 and fT3 levels when serum samples were analyzed by a commercial procedure from diluted serum, but not when an ultrafiltration method from undiluted serum was used. The authors concluded that their results further support the view that hepatic P-450 enzyme induction is not the main or the only reason for decreased thyroid hormone concentrations during CBZ treatment. However, the mechanism of thyroid dysfunction with VPA is still unknown.

In this study, thyroid enlargement was reported in one fourth of patients (26\% versus $6.67 \%$ controls) which represents $46.05 \%$ of patients with lab evidence of SCH. The higher frequency of patients with thyroid enlargement were on combined therapy $(C B Z+V P A)(45 \%)$ followed by those on VPA (30\%). Previous studies reported thyroid enlargement with enzyme-inducing and non-enzyme inducing AEDs $(5,29,40)$. Hegedüs et al. (5) reported increased thyroid volume with CBZ (range: 13-66 ml, mean: 25 $\mathrm{ml}$; versus range: 9-44 ml, mean: $16 \mathrm{ml}$ for controls; $p<0.010)$. The authors reported an associated between the thyroid volume and reduced serum levels of T4, fT4I and fT3I and increased serum level of thyroglobulin but normal serum levels of T3, T3RU and TSH. Chakova et al. (29) reported thyroid enlargement in $18.2 \%$ of the children on long-term treatment with AEDs. Clinical signs of initial hyperplasia of the thyroid gland were observed in $13.64 \%$. The ultrasound examination revealed slight structural changes, decreased colloid uptake, and strip-like sprouts in $63.6 \%$ particularly with combined AEDs (polytherapy) (54.55\%). The authors reported associated between thyroid enlargement and abnormalities in the thyroid hormones and thyrotropin serum concentration (22.73\%). However in contrast, normal thyroid volume was reported despite lower levels of T4, fT4 and T3. with CBZ and VPA (41). The identified significant correlations between thyroid volume and thyroid hormones abnormalities found in this and other studies highly suggest that the increase in thyroid volume is probably a compensatory mechanism due to the low serum concentrations of fT4 and compensatory reduced concentrations of $\mathrm{fT} 3$ and enhanced concentrations of TSH regardless of the type of AEDs (enzyme-inducing versus non-enzyme inducing AEDs).

Despite the strength of this study, it has some limitations: 1) the recruitment of the study group from a tertiary care center (a University hospital) with more severe cases and this explains the high percentage of thyroid hormonal and volume abnormalities. However, it should be kept in mind that $\mathrm{SCH}$ is a relatively common condition with incidence between 3 to $7 \%$ in the general population (42). The prevalence of the disease is approximately $20 \%$ (43). Hence probably, such frequency rates for developing $\mathrm{SCH}$ might be increased among the patients with epilepsy group of population, which is also common, and $\mathbf{2}$ ) because of the cross-sectional nature of the present study, it was not possible to know temporal relationship between thyroid dysfunction to the use of AEDs. However, such limitations could only be overcomed through a longitudinal and multi-center study design.

\section{Conclusions}

CBZ and VPA as mono- or poly- therapies may cause thyroid hormonal and structural abnormalities. The increased thyroid volume is probably due to associated subclinical hypothyroidism $(\mathrm{SCH})$. This data indicates the importance of monitoring thyroid function in patients with epilepsy and on treatment with AEDs. This data also may have implications suggesting prevention strategies. 


\section{Conflict of interests}

The authors declare that they have no competing interests. Authors did not receive fund for this work and all were authors' responsibility.

\section{References}

1. Hauser WA, Annegers JF, Kurland LT. Incidence of Epilepsy and Unprovoked Seizures in Rochester, Minnesota: 1935-1984. Epilepsia 1993;34(3),453-468.

2. Magiera J. Functional disorders of the hypothalamo-pituitarythyroid axis in epilepsy. Neurol Neurochir Pol 1987;21(6):498503.

3. Yuksel A, Yalcin E, Cenani A. Influence of long-term carbamazepine treatment on thyroid function. Acta Paediatr Jpn 1993;35(3):229-232.

4. Strandjord RE, Aanderud S, Myking OL, Johannessen SI. Influence of carbamazepine on serum thyroxine and triiodothyronine in patients with epilepsy. Acta Neurol Scand 1981;63(2):111-121.

5. Hegedüs L, Hansen JM, Lühdorf $K$, Perrild $H$, Feldt-Rasmussen $U$, Kampmann JP. Increased frequency of goitre in epileptic patients on long-term phenytoin or carbamazepine treatment. Clin Endocrinol (Oxf) 1985;23(4):423-429.

6. Connacher AA, Borsey DQ, Browning MC, Davidson DL, Jung RT. The effective evaluation of thyroid status in patients on phenytoin, carbamazepine or sodium valproate attending an epilepsy clinic. Postgrad Med J 1987;63(744):841-845.

7. Larkin JG, Macphee GJ, Beastall GH, Brodie MJ. Thyroid hormone concentrations in epileptic patients. Eur J Clin Pharmacol 1989;36(3):213-216

8. Isojarvi JI, Pakarinen AJ, Myllyla VV. Thyroid function with antiepileptic drugs. Epilepsia 1992;33(1):142-148.

9. Caksen $H$, Dulger $H$, Cesur $Y$, Odabas $D$, Tuncer $O$, Atas B.No effect of long-term valproate therapy on thyroid and parathyroid functions in children. Int J Neurosci 2002;112(11):1371-1374.

10. Liewendahl K, Majuri H, Helenius, T. Thyroid function test in patients on long-term treatment with various anticonvulsant drugs. Clin Endocrinol 1978;8(3):185-191.

11. Rootwelt K, Ganes T, Johannessen SI.Effect of carbamazepine, phenytoin and phenobarbitone on serum levels of thyroid hormones and thyrotropin in humans. Scand J Clin Lab Invest 1978;38(8):731-736.

12. Bentsen KD, Gram L, Veje A. Serum thyroid hormones and blood folic acid during monotherapy with carbamazepine or valproate. Acta Neurol Scand 1983;67(4);235-241.

13. Ericsson UB, Bjerre I, Forsgren M, Ivarsson SA.Thyroglobulin and thyroid hormones in patients on long-term treatment with phenytoin, carbamazepine, and valproic acid. Epilepsia 1985;26(6):594-596.

14. Isojarvi JIT, Pakarinen AJ, Ylipalosaari, PJ, Myllyla VV. Serum hormones in male patients with epilepsy patients receiving anticonvulsant medication. Arch Neurol 1990;47(6):670-676.

15. Eiris-Punal J, Del Rio-Garma M, Del Rio-Garma MC, LojoRocamonde S, Novo-Rodriguez I, Castro-Gago M. Longterm treatment of children with epilepsy with valproate or carbamazepine may cause subclinical hypothyroidism. Epilepsia 1999;40(12):1761-1766.

16. Verrotti A, Basciani F, Morresi S, Morgese G, Chiarelli F.Thyroid hormones in epileptic children receiving carbamazepine and valproic acid. Pediatr Neurol 2001;25(1):43-46.

17. Hamed SA, Hamed EA, Kandil MR, El-Shereef HK, Abdellah MM, Omar H. Serum Thyroid Hormone Balance and Lipid Profile in Patients with Epilepsy. Epilepsy Res 2005;66(1-3):173-183.

18. Cansu A, Serdaroglu A, Camurdan O, Hirfanoglu T, Bideci $A$, Gücüyener K.The evaluation of thyroid functions, thyroid antibodies, and thyroid volumes in children with epilepsy during short-term administration of oxcarbazepine and valproate. Epilepsia 2006;47(11):1855-1859.

19. Mikati MA, Tarabay H, Khalil A, Rahi AC, El Banna D, Najjar S. Risk factors for development of subclinical hypothyroidism during valproic acid therapy. J Pediatr 2007;151(2):178-181.

20. Attilakos A, Katsarou E, Prassouli A, Mastroyianni S, Voudris K, Fotinou A, Garoufi A. Thyroid function in children with epilepsy treated with sodium valproate monotherapy: a prospective study. Clin Neuropharmacol 2009;32(1):32-34.

21. Aggarwal A, Rastogi N, Mittal H, Chillar N, Patil R. Thyroid hormone levels in children receiving carbamazepine or valproate. Pediatr Neurol 2011;45(3):159-162.

22. Aygün F, Ekici B, Aydinli N, Aydin BK, Bas F, Tatli B. Thyroid hormones in children on antiepileptic therapy. Int J Neurosci 2012;122(2):69-73.

23. Kim SH, Chung HR, Kim SH, Kim H, Lim BC, Chae JH, Kim KJ, Hwang YS, Hwang $H$. Subclinical hypothyroidism during valproic acid therapy in children and adolescents with epilepsy. Neuropediatrics 2012;43(3):135-139.

24. Sahu JK, Gulati S, Kabra M, Arya R, Sharma R, Gupta N, Kaleekal T, Reeta Kh, Gupta YK. Evaluation of subclinical hypothyroidism in ambulatory children with controlled epilepsy on valproate monotherapy. J Child Neurol 2012;27(5):594-597.

25. Yılmaz U, Yılmaz TS, Akıncı G, Korkmaz HA, Tekgül H.The effect of antiepileptic drugs on thyroid function in children. Seizure 2014;23(1):29-35.

26. Vainionpää LK, Mikkonen K, Rättyä J, Knip M, Pakarinen AJ, Myllylä VV, Isojärvi Jl. Thyroid function in girls with epilepsy with carbamazepine, oxcarbazepine, or valproate monotherapy and after withdrawal of medication. Epilepsia 2004;45(3):197-203.

27. Lossius MI, Taubøll E, Mowinckel P, Gjerstad L. Reversible effects of antiepileptic drugs on thyroid hormones in men and 
women with epilepsy: a prospective randomized double-blind withdrawal study. Epilepsy Behav 2009;16(1):64-68.

28. De Luca F, Arrigo T, Pandullo E, Siracusano MF, Benvenga $S$, Trimarchi F.Changes in thyroid function tests induced by 2 month carbamazepine treatment in L-thyroxine-substituted hypothyroid children. Eur J Pediatr 1986;145(1-2):77-79.

29. Chakova L, Karakhanian E, Dimitrov H, Lutakova E. Effect of antiepileptic drugs on the thyroid gland in children with epilepsy (preliminary report). Folia Med (Plovdiv) 1998;40(1):80-83

30. Isojarvi JI, Turkka J, Pakarinen AJ, Kotila M, Rattya J, Myllyla VV. Thyroid function in men taking carbamazepine, oxcarbazepine, or valproate for epilepsy. Epilepsia 2001,42(7):930-934.

31. Tsukui $T$, Aizawa $T$, Yamada $T$, Kawabe T. Studies on the mechanism of goitrogenic action of diphenylthiohydantoin. Endocrinology 1978;102(6):1662-1669.

32. Proposal for revised classification of epilepsies and epileptic syndromes. Commission on Classification and Terminology of the International League Against Epilepsy. Epilepsia 1989;30(4):389-399.

33. Diagnostic Product Corporation, 1987. Albumin-Related Artifacts in Free Thyroid Hormone Assays. Los Angeles.

34. Witherspoon LR, el Shami AS, Shuler SE, Neely H, Sonnemake R, Gilbert SS, Alyea K. Chemically blocked analog assays for free thyronines. I. The effect of chemical blockers on T4 analog and T4 binding by albumin and by thyroxin-binding globulin. Clin Chem 1988:34(1):9-16.

35. Babson AL, Olson DR, Palmieri T, Ross AF, Becker DM, Mulqueen PJ. The IMMULITE assay tube: a new approach to heterogeneous ligand assay. Clin Chem 1991;37(9):1521-1522.

36. Zimmermann $P$, Takala $T$, Poyhonen $L$, Punnonen $R$. Ultrasonography of the thyroid gland in pregnancies complicated by autoimmune thyroid disease. J Clin Ultrasound 1993;21(12):109-113.

37. Hamed SA. Neuroendocrine hormonal conditions in epilepsy: relationship to reproductive and sexual functions. Neurologist 2008,14(3):157-169.

38. Villa SM, Alexander NM. Carbamazepine (Tegretol) inhibits in vivo iodide uptake and hormone synthesis in rat thyroid glands. Endocr Res 1997;13(4):385-397.

39. Surks MI, DeFesi CR. Normal serum free thyroid hormone concentrations in patients treated with phenytoin or carbamazepine. JAMA 1996;275(19):149-158.

40. Gerber H, Huber G, Peter HJ, Kämpf J, Lemarchand-Beraud T, Fragu P, Stocker R. Transformation of normal thyroids into colloid goiters in rats and mice by diphenylthiohydantoin. Endocrinology 1994;135(6):2688-2699.

41. Hirfanoglu $T$, Serdaroglu A, Camurdan O, Cansu A, Bideci $A$, Cinaz P, Gucuyener K. Thyroid function and volume in epileptic children using carbamazepine, oxcarbazepine and valproate. Pediatr Int 2007;49(6):822-826.

42. Spacilova J, Limanova Z, Aschermann M. Subclinical hypothyroidism with emphasis on the cardiovascular system. Cas Lek Cesk 2003;142(11):643-647.

43. Weissel M. Possible consequences of subclinical hypothyroidism. Acta Med Austriaca 2003;30(4):93-97.

\section{Comment on this article:}
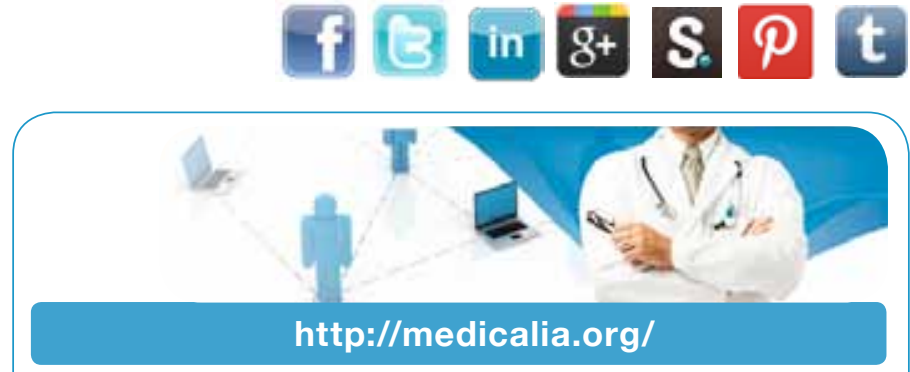

Where Doctors exchange clinical experiences, review their cases and share clinical knowledge. You can also access lots of medical publications for free. Join Now!

\section{Publish with iMedPub}

\section{http://www.imed.pub}

Neurology and Neuroscience (jneuros.com) is a hybrid, peerreviewed journal that considers articles concerned with any aspect of clinical neurosciences such as neurology, psychiatry and neurosurgery, as well as basic research on neuroscience where neurologists and neuroscientists publish together.

\section{Submit your manuscript here: http://www.jneuros.com}

